\title{
Mitigation of Wastewater-Borne Chorpyrifos in Constructed Wetlands: an Ecological Suitability Assessment by Macrophyte and Microbial Responses
}

\author{
Chuan Wang', ${ }^{1,}$ Biyun Liu ${ }^{1}$, Dong Xu' ${ }^{1}$, Liping Zhang1, Feng He', \\ Qiaohong Zhou ${ }^{1 *}$, Zhenbin Wu ${ }^{1}$ \\ ${ }^{1}$ State Key Laboratory of Freshwater Ecology and Biotechnology, Institute of Hydrobiology, \\ Chinese Academy of Sciences, Wuhan 430072, China \\ ${ }^{2}$ University of Chinese Academy of Sciences, Beijing 100049, China
}

Received: 19 September 2016

Accepted: 12 December 2016

\begin{abstract}
Plants and microorganisms are the main biotic compartments for phytoaccumulation and metabolic transformation of organic contaminants in constructed wetlands (CWs). However, how they cope with special pollutants during the treatment process has not been well characterized. In this study, responses of Iris pseudoacorus (I. pseudoacorus) and microbial communities were intensively investigated in pilot-scale CWs treating wastewater-borne chlorpyrifos, an organic phosphorus pesticide. Chlorpyrifos was associated with inhibited plant growth, decreased photosynthetic activity, and a significant increase in oxidative products. Superoxide dismutase (SOD) and ascorbate peroxidase (APX) activities were affected by chlorpyrifos, whereas catalase (CAT) activity was almost unaffected. Although chlorpyrifos stimulated the antioxidant system, there was little indication of oxidative damage in I. pseudoacorus. Urease, $\beta$-glucosidase, and phosphatase activities in substrate were elevated by $73.73 \%, 17.20 \%$, and $16.23 \%$, respectively, which may indicate enhancement of nitrogen, carbon, and phosphorus cycling. Fatty acid methyl ester (FAME) profiles showed that aerobic prokaryotes, which are likely the functional group responsible for chlorpyrifos degradation, increased from $16.37 \%$ to $31.32 \%$ after chlorpyrifos addition. Biomarkers for fungal/bact and trans/cis remained unchanged after the chlorpyrifos addition, suggesting that chlorpyrifos did not negatively influence the substrate microbial communities in CWs.
\end{abstract}

Keywords: constructed wetlands (CWs), chlorpyrifos, oxidative product, antioxidant enzyme, fatty acid methyl ester (FAME)

*e-mail: qhzhou@ihb.ac.cn 


\section{Introduction}

Chlorpyrifos, a broad spectrum organophosphate insecticide, is applied on a large scale in croplands for the control of foliar insects [1-3]. Approximately $140,000 \mathrm{t}$ of chlorpyrifos are applied annually on a global scale, accounting for $1 / 3$ of total organophosphorus pesticide use. Annually, 5,000 t (of the active ingredient) are used in the United States and 18,000 t are used in China [4-5]. Chlorpyrifos and other pesticides may have negative effects on non-target aquatic invertebrates and fish through irrigation runoff, in which pesticides are either dissolved or particle-associated [6].

Constructed wetlands (CWs) are ecosystems containing substrate, microorganisms, and plants that have been proposed as structural best management practices for the mitigation of chlorpyrifos contamination in agriculturally dominated watersheds [7]. Results from field studies indicate that CWs can efficiently remove pesticides from agricultural runoff. Stearman et al. evaluated pesticide removal rates with different wetland areas and flow rates, and found that the optimal combination eliminated $90.2 \%$ of added metolachlor and $83 \%$ of added simazine [8]. A field experiment in Norway showed that CWs reduced mean pesticide peak concentrations up to $91 \%$ in vegetated wetland cells [9].

However, stress caused by exogenous chlorpyrifos also needs to be considered. Antioxidative enzymes and oxidative products are often used as indicators of plant physiological stress caused by pesticides or herbicides [10-11]. Antioxidative enzymes, which act as scavengers of reactive oxygen intermediates (ROIs) in plants, can be elevated under stressful conditions [12]. Superoxide dismutase (SOD) acts as the first line of antioxidative defense and converts superoxide anion $\left(\mathrm{O}_{2}^{-}\right)$into hydrogen peroxide $\left(\mathrm{H}_{2} \mathrm{O}_{2}\right)$, after which ascorbate peroxidase (APX) and catalase (CAT) detoxify $\mathrm{H}_{2} \mathrm{O}_{2}$ into $\mathrm{O}_{2}$ and malonaldehyde (MDA) [12]. Water-soluble sugar (WSS) functions as osmotic adjustment to relieve injuries to the plasmalemma [13].

Enzymatic activities in soil microorganisms are sensitive indicators that can be used to monitor changes in soils [14]. Urease, $\beta$-Glucosidase, and phosphatase are used as bioactivity indices in soils, sediments, and other substrates. Urease, $\beta$-glucosidase, and phosphatase are responsible for hydrolysis of urea, degradation of cellulose, and cleavage of a variety of ester-phosphate bonds, respectively, forming inorganic nutrients and maintaining biological soil quality [15-18]. Ester-linked fatty acid methyl ester (EL-FAME) profiles have been widely used to "fingerprint" microbial communities in various environments [19-20], which is a useful tool for the study of microbial communities in contaminated soils and aquifers, and for the evaluation of recovery following reclamation [21-23].

Most studies related to pesticides and CWs have focused on the effectiveness of remediation technologies, and few have included ecological suitability assessment of the technology itself. In the present study, the responses of biosystems in CWs, including macrophytes and microorganisms, were evaluated during the process of chlorpyrifos removal from contaminated water.

\section{Material and Methods}

\section{Pilot-Scale CWs}

Experimental systems were placed in the open air in Wuhan, China (30.55 E and 114.36 N). Six pilot-scale vertical flow CWs were made from polyethylene (PE) columns with a height of $600 \mathrm{~mm}$ and a diameter of $500 \mathrm{~mm}$. Each column was filled to a depth of $300 \mathrm{~mm}$ with washed river sand (mainly $\mathrm{Si}_{2} \mathrm{O}_{3}, \mathrm{Al}_{2} \mathrm{O}_{3}$, $\mathrm{Fe}_{2} \mathrm{O}_{3}, 1-5 \mathrm{~mm}$ in diameter) as substrate and planted with three uniform Iris pseudoacorus (I. pseudoacorus).

\section{Experimental Design and Sampling}

During a 15-day acclimatization stage, each column received synthetic wastewater containing $7-8 \mathrm{mg} \mathrm{L}^{-1}$ of total nitrogen (TN), 0.2-0.4 $\mathrm{mg} \mathrm{L}^{-1}$ of total phosphorus (TP), and $60-70 \mathrm{mg} \mathrm{L}^{-1}$ of chemical oxygen demand $\left(\mathrm{COD}_{\mathrm{Cr}}\right)$ as inflow water. The average removal rates of three batches for TN, TP, and $\mathrm{COD}_{\mathrm{Cr}}$ were $63.37 \%$, $80.96 \%$, and $90.31 \%$, respectively (Table 1). A 30-day experimental stage followed immediately after acclimation. In the experimental stage, three of the CWs were assigned to a control group and three CWs were assigned to a chlorpyrifos treatment group. Chlorpyrifos was added into the inflow water of the latter group with a final

Table 1. Purification effects for water quality indices TN, TP, and $\mathrm{COD}_{\mathrm{Cr}}$ from constructed wetlands.

\begin{tabular}{|c|c|c|c|c|c|c|c|}
\hline & \multicolumn{2}{|c|}{ Batch 1} & \multicolumn{2}{|c|}{ Batch 2} & \multicolumn{2}{|c|}{ Batch 3} & \multirow{2}{*}{$\begin{array}{c}\text { Average removal } \\
\text { rate }(\%)\end{array}$} \\
\hline & Influent & Effluent & Influent & Effluent & Influent & Effluent & \\
\hline $\begin{array}{c}\mathrm{TN} \\
\left(\mathrm{mg} \mathrm{L}^{-1}\right)\end{array}$ & $7.22 \pm 0.13$ & $1.96 \pm 0.37$ & $6.99 \pm 0.08$ & $3.01 \pm 0.34$ & $7.06 \pm 0.01$ & $2.79 \pm 0.24$ & $63.37 \pm 8.26$ \\
\hline $\begin{array}{c}\mathrm{TP} \\
\left(\mathrm{mg} \mathrm{L}^{-1}\right)\end{array}$ & $0.24 \pm 0.00$ & $0.03 \pm 0.01$ & $0.36 \pm 0.00$ & $0.08 \pm 0.01$ & $0.38 \pm 0.01$ & $0.08 \pm 0.01$ & $80.96 \pm 4.91$ \\
\hline $\begin{array}{c}\mathrm{COD} \\
\left(\mathrm{mg} \mathrm{L}^{-1}\right)\end{array}$ & $64.00 \pm 5.66$ & $11.67 \pm 3.50$ & $62.50 \pm 0.71$ & $3.50 \pm 1.47$ & $64.50 \pm 6.36$ & $6.60 \pm 4.91$ & $90.31 \pm 6.06$ \\
\hline
\end{tabular}


concentration of $1 \mathrm{mg} \mathrm{L}^{-1}$. This concentration is between the solubility $\left(1.39 \mathrm{mg} \mathrm{L}^{-1}\right.$ at $\left.25^{\circ} \mathrm{C}\right)$ of chlorpyrifos and the chlorpyrifos concentration of contaminated water in the field [24-25]. The hydraulic load was $25.48 \mathrm{~mm} \mathrm{~d}^{-1}$ and the hydraulic retention time (HRT) was two days.

\section{Macrophyte Growth and Chlorophyll Measurements}

Young leaves grew out after the acclimatization stage, and the lengths of these leaves were measured at the start and end of the experimental stage. The number and length of withered leaves were also recorded. Chlorophyll was extracted by ethanol $(96 \%, v / v)$ and detected by spectrophotometry. The formulas used to calculate the fresh concentrations of chlorophyll a, chlorophyll b, and carotenoid are as follows:

- chlorophyll a $($ Chla $)=\left(13.95 \mathrm{~A}_{663}-6.88 \mathrm{~A}_{649}\right) \times$ total volume/fresh weight

- chlorophyll b $(\mathrm{Chlb})=\left(24.96 \mathrm{~A}_{649}-7.32 \mathrm{~A}_{665}\right) \times$ total volume/fresh weight

- $\operatorname{carotenoid}(\mathrm{Car})=\left(1000 \mathrm{~A}_{470}-2.05 \mathrm{C}_{\mathrm{a}}-114.8 \mathrm{C}_{\mathrm{b}}\right) / 245 \times$ total volume/fresh weight

\section{Oxidative Products and Antioxidant Enzymes}

WSS and $\mathrm{H}_{2} \mathrm{O}_{2}$ levels were determined colorimetrically and MDA was measured using the thiobarbituric acid method as described by Kong and Lin [26-27].

Fresh tissue $(0.5 \mathrm{~g})$ was homogenized in $5 \mathrm{~mL}$ cold $\mathrm{K}_{2} \mathrm{HPO}_{4} / \mathrm{KH}_{2} \mathrm{PO}_{4}$ buffer (50 mM, pH 7.0), which included $1 \% \quad(\mathrm{w} / \mathrm{v})$ polyvinylpyrrolidone. The homogenates were centrifuged at $10,000 \mathrm{rpm}$ for $20 \mathrm{~min}$ at $4^{\circ} \mathrm{C}$. The supernatant was used for activities of SOD, APX, and CAT assays.

The activity of SOD was determined by monitoring the inhibition of photochemical reduction of nitrobluetetrazolium (NBT). The reaction mixture $(9 \mathrm{~mL})$ contained $50 \mathrm{mM}$ potassium phosphate buffer $(\mathrm{pH}$ 7.8), $2 \mathrm{mM}$ riboflavin, $75 \mathrm{mM}$ NBT, $13 \mathrm{mM}$ DL methionine, $100 \mathrm{mM}$ EDTA, and enzyme extract $(0.15 \mathrm{~mL})$. The reaction was initiated by illuminating the reaction mixture with 4,000 1x-light intensity for $20 \mathrm{~min}$ at $25^{\circ} \mathrm{C}$ and absorbance was read at $560 \mathrm{~nm}$. Identical tubes that were not illuminated served as blanks and those containing $50 \mathrm{~mL}$ of $50 \mathrm{mM}$ phosphate buffer ( $\mathrm{pH} 7.8)$ in place of the enzyme extract served as positive controls. One unit of activity was determined as the amount of enzyme extract required to inhibit the photoreduction of NBT to blue formazan by $50 \%$ and was expressed as SOD units $\mathrm{mg}^{-1}$.

The activity of APX was determined at $290 \mathrm{~nm}$ by spectrophotometrically modifying the rate of ascorbate oxidation at $25^{\circ} \mathrm{C}$. The reaction mixture $(9 \mathrm{~mL})$ consisted of $50 \mathrm{mM}$ potassium phosphate buffer ( $\mathrm{pH} 7.0$ ), $0.1 \mathrm{mM}$ EDTA, $0.5 \mathrm{mM}$ ascorbate, and $0.1 \mathrm{mM} \mathrm{H}_{2} \mathrm{O}_{2}$. The reaction was initiated by adding $0.1 \mathrm{~mL}$ enzyme extract to the reaction mixture. One unit of enzyme activity was calculated as the amount of enzyme extract required to oxidize $1 \mathrm{mM}$ of ascorbate (mg $\mathrm{min})^{-1}$.
The specific activity of CAT was measured according to the decomposition rate of $\mathrm{H}_{2} \mathrm{O}_{2}$. The reaction mixture $(12 \mathrm{~mL})$ contained $0.8 \mathrm{~mL}$ of enzyme extract, $0.2 \mathrm{M}$ phosphate buffer ( $\mathrm{pH} 7.8,6 \mathrm{~mL})$, distilled water $(4 \mathrm{~mL})$, and $10 \mathrm{mM} \mathrm{H}_{2} \mathrm{O}_{2}(1.2 \mathrm{~mL})$. CAT activity was estimated at $25^{\circ} \mathrm{C}$ by monitoring the decrease in absorbance of $\mathrm{H}_{2} \mathrm{O}_{2}$ at $240 \mathrm{~nm}$ and was expressed as $\mathrm{mM}$ of $\mathrm{H}_{2} \mathrm{O}_{2}$ decomposed (mg min) $)^{-1}$.

\section{Enzyme Activity and EL-FAME Analysis of Substrate}

The activities of urease, $\beta$-glucosidase, and phosphatase were measured as previously described [28].

Mild alkaline methanolysis was used for the extraction of EL-FAMEs as described by [29] with some modifications. Six grams of soil was placed in a $50 \mathrm{~mL}$ teflon-lined screw-cap test tube and was mixed with $15 \mathrm{~mL} 0.2 \mathrm{M} \mathrm{KOH}$ in $\mathrm{MeOH}$. Cells were lysed and saponified by incubating the test tubes at $37^{\circ} \mathrm{C}$ for $1 \mathrm{~h}$ and gently agitating them every $10 \mathrm{~min}$. After incubation, $3 \mathrm{~mL} 1 \mathrm{M}$ acetic acid was added to adjust the $\mathrm{pH}$ of the mixture. Then $10 \mathrm{~mL}$ hexane was added to extract the FAMEs from the aqueous phase into the organic phase. Soil samples were centrifuged at $4,800 \mathrm{rpm}$ for 10 min to separate soil organic matter from the organic phase. The organic phase was then transferred to a gas chromatograph (GC) vial, evaporated under a stream of $\mathrm{N}_{2}$, and finally redissolved into $0.5 \mathrm{~mL}$ hexane.

GC analysis was performed using an Agilent $6890 \mathrm{~N}$ gas chromatograph (Agilent Technologies, USA), equipped with an Agilent 5793 inertMSD. A fused silica capillary column (DB $5 \mathrm{~ms}, 0.25 \mathrm{~mm} \times 30 \mathrm{~mm}$ $\times 0.25 \mu \mathrm{m})$ was employed. The GC oven temperature program consisted of an initial temperature of $80^{\circ} \mathrm{C}$ for $2 \mathrm{~min}$, with a ramp of $50^{\circ} \mathrm{C} \mathrm{min}^{-1}$ to $150^{\circ} \mathrm{C}$ and holding for $2 \mathrm{~min}$, a ramp of $2.5^{\circ} \mathrm{C} \mathrm{min}^{-1}$ to $195^{\circ} \mathrm{C}$ and holding for $2 \mathrm{~min}$, and finally a ramp of $2.5^{\circ} \mathrm{C} \mathrm{min}^{-1}$ to $215^{\circ} \mathrm{C}$ and holding for $5 \mathrm{~min}$. The injector temperature was $250^{\circ} \mathrm{C}$ and the injected volume was $1 \mu \mathrm{L}$. Helium (purity $>99.999 \%$ ) was used as carrier gas at a constant flow rate of $1.0 \mathrm{~mL} \mathrm{~min}^{-1}$.

\section{Data Analysis}

Differences between control and treatment groups, and between young and adult leaves were analyzed by one-way ANOVA with least significant difference (LSD) for multiple comparisons. Calculations were made with support from the statistical program SPSS, version 16.0 .

To ascertain the soil microbial community composition, individual percentage of FAMEs of the substrate samples were first subjected to detrended correspondence analysis (DCA). According to the length of the first gradient (0.797), principal component analysis (PCA) of unstrained ordination based on a correlation matrix was used (CANOCO software 4.5). The data were $\log (x+1)$, transformed to allow analysis of patterns 
related to the whole community by weighing rare fatty acids (FAs) similarly to common FAs.

\section{Results and Discussion}

\section{Macrophyte Growth and Chlorophyll}

Throughout the experiment, new leaves formed and young leaves elongated. However, terminal wilting was also observed in adult leaves. Chlorpyrifos significantly inhibited the growth of I. pseudoacorus (Fig. 1a). Compared with the start of the experimental stage, the leaf number and length at the end of experiment increased by $16.28 \%$ and $14.29 \%$, respectively, in the treatment group, and by $32.44 \%$ and $33.85 \%$, respectively, in the control group. The withering rate was not significant between groups.

There was no difference in Chla, Chlb, and Car between young and adult leaves, so data were combined before evaluating differences between the treatment and control groups. The concentrations of Chla, Chlb, and Car were all significantly lower in the treatment group than in the control group $(25.04 \%, 20.94 \%$, and $19.02 \%$ lower, respectively; Fig. 1b). Total chlorophyll and carotenoid are reported to decrease with increasing concentrations of a pesticide mixture that includes chlorpyrifos, atrazine, metalaxyl, disulfoton, and ethion [30]. These decreases in pigment content can be partially explained by herbicidal effects on photosystem II (PSII), but can also be attributed to the adverse effects of pesticides on photosynthetic electron transport capacity. Carotenoids function as light-harvesting pigments and prevent photochemical formation of singlet oxygen via chlorophyll [31]. Consequently, macrophytes with decreased chlorophyll and carotenoid content may be vulnerable to oxidative intimidation that results in a decrease of photosynthetic efficiency.

Ratios of Chla/Chlb and Car/Chla were larger in young control leaves than in mature control leaves, whereas there were no differences in these ratios within the treatment group (Fig. 1c). The two ratios were more sensitive to chlorpyrifos in young leaves than that in mature leaves. There was no difference between control and treated mature leaves in the Chla/Chlb or Car/Chla ratio. However, in young leaves, Chla/Chlb was 3.27 for controls and 3.02 for treated plants, and Car/Chla was 0.19 for controls and 0.21 for treated plants. Although the difference in Car/Chla between treated and control young leaves was statistically significant, it was quite small. Reductions in Chla/Chlb after pesticide exposure have been described as an indicator of increased grana stacking, reduced intergrana lamellae, and elevated PSII/PSI ratio, which results in an increased capacity for post-illumination ATP production [32]. Car/Chla generally increases after being treated with herbicides [33]. He et al. reported that Cars/Chla ratios in various species increased after treatment with herbicides, such as bentazon and molinate treatment of Anabaena cylindrical, oxyfluorfen treatment of Nostoc muscorum and Phormidium foveolarum, and 2,4-D treatment of Anabaena fertilissima [34].
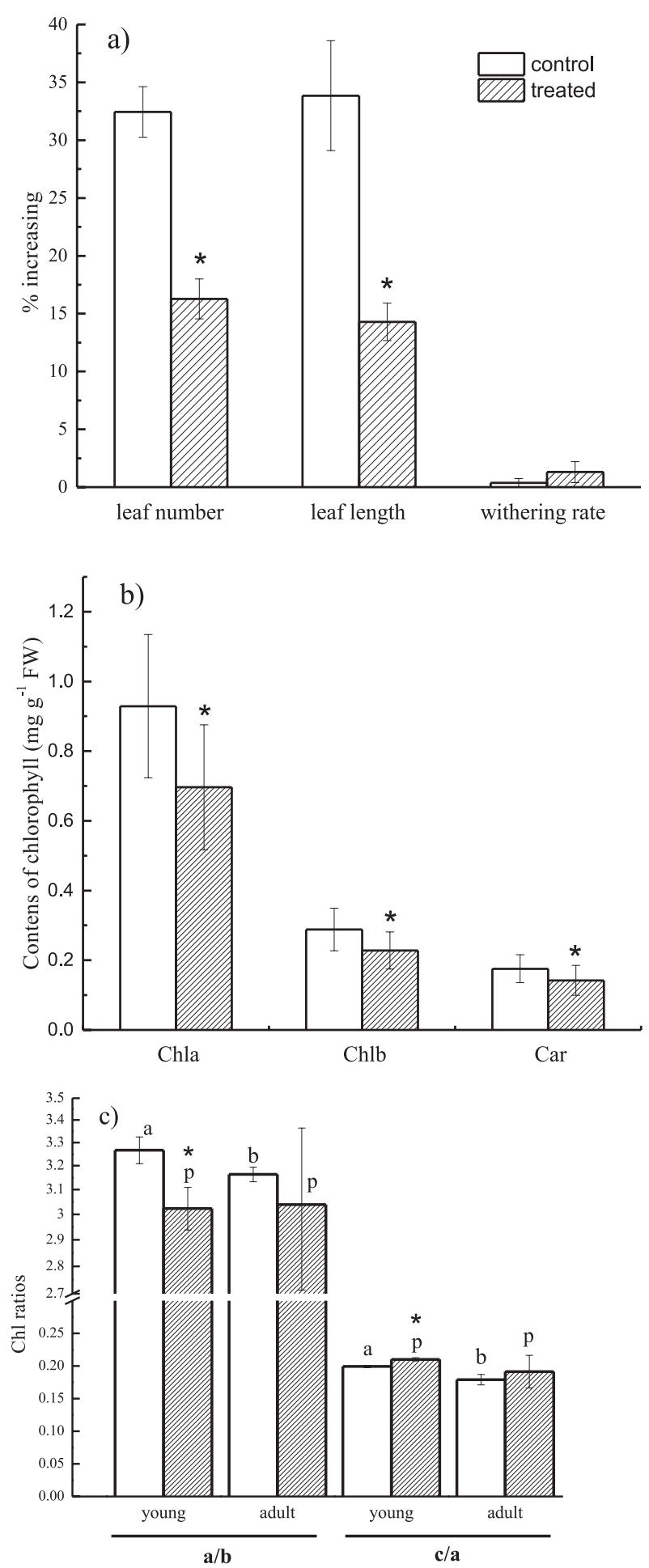

Fig. 1 Macrophyte growth and chlorophyll levels after chlorpyrifos treatment. Data are presented as means $\pm \mathrm{SE}(\mathrm{n}=$ 9). Different letters ( $a, b$ or $p, q)$ indicate significant differences between young and mature leaves. Asterisks $(*)$ indicate significant differences between control and treated groups (oneway ANOVA, $\mathrm{p}<0.05)$. 


\section{Oxidative Products and Antioxidant Enzyme Activities}

Concentrations of WSS and MDA in young leaves were lower than those in mature leaves within the control group; however, no such differences were found within the treatment group. $\mathrm{H}_{2} \mathrm{O}_{2}$ concentration was higher in young leaves than in mature leaves in both the control and treatment groups (Fig. 2a). In both young and mature leaves, WSS, $\mathrm{H}_{2} \mathrm{O}_{2}$, and MDA concentrations were greater in the chlorpyrifos treatment group than in the control group. Relative to the concentrations of these substances in leaves from treated plants, concentrations in young and mature leaves from control plants were $72.99 \%$ and $26.55 \%$ greater, respectively (WSS); $63.67 \%$ and $176.62 \%$ greater, respectively $\left(\mathrm{H}_{2} \mathrm{O}_{2}\right)$; and $35.69 \%$ and $14.57 \%$ greater, respectively (MDA).

There was no difference in SOD activity in young and mature leaves. CAT activity was greater in young
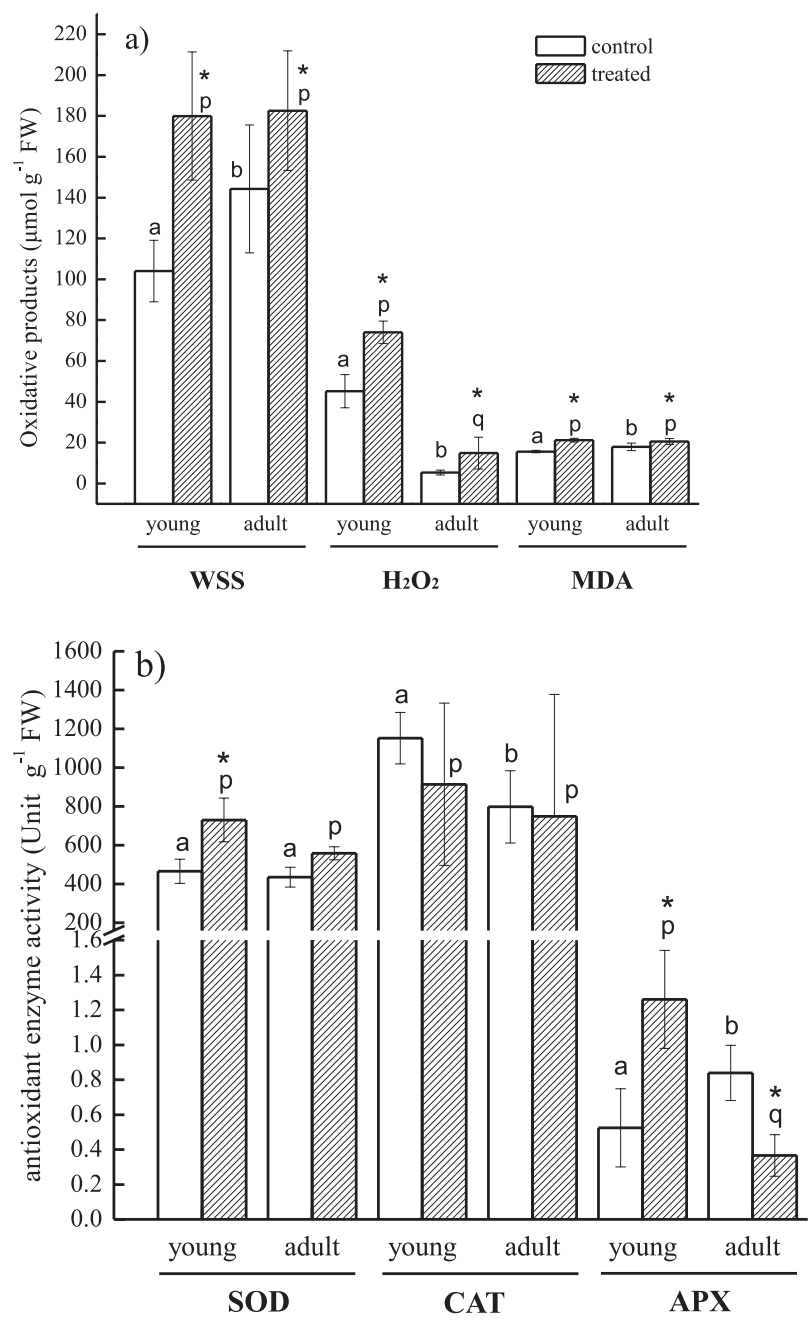

Fig. 2. Effect of chlorpyrifos on antioxidant enzyme activities in I. pseudoacorus leaves. Data are presented as means $\pm \mathrm{SE}$ $(\mathrm{n}=9)$. Different letters $(\mathrm{a}, \mathrm{b}$ or $\mathrm{p}, \mathrm{q})$ indicate significant differences between young and mature leaves. Asterisks $(*)$ indicate significant differences between control and treated groups (one-way ANOVA, $\mathrm{p}<0.05$ ). control leaves than in mature control leaves, but there was no difference between young and mature treated leaves. APX activity was lower in young control leaves than in mature control leaves, whereas it was higher in young treated leaves than in mature treated leaves (Fig. 2b). Chlorpyrifos stimulated SOD activity in young leaves, but had no effect on CAT activity. APX was stimulated by chlorpyrifos in young leaves, but was inhibited by chlorpyrifos in mature leaves.

The balance between SOD and APX or CAT activities in cells is crucial for determining the steady-state level of $\mathrm{H}_{2} \mathrm{O}_{2}$ and superoxide radicals [35]. SOD acts as the first line of defense converting $\mathrm{O}_{2}^{-}$into $\mathrm{H}_{2} \mathrm{O}_{2}$, APX, and CAT, and then detoxifying $\mathrm{H}_{2} \mathrm{O}_{2}$ into $\mathrm{O}_{2}$ and MDA [12]. Consequently, an increase in SOD activity would lead to a corresponding increase in $\mathrm{H}_{2} \mathrm{O}_{2}$ level, which was consistent with the results presented in section 3.2. It has been proposed that APX may be responsible for the fine modulation of reactive oxygen intermediates (ROIs) for signaling, whereas CAT is responsible for the removal of excess ROIs during stress [12]. Given that we found no change in CAT activity with exposure to chlorpyrifos, it is unlikely that the $\mathrm{H}_{2} \mathrm{O}_{2}$ levels we observed didn't cause oxidative damage. As indicated by the results presented in Fig. 1, chlorpyrifos didn't cause any physiological damage except for the inhibition of I. pseudoacorus growth.

\section{Substrate Enzyme Activities}

Urease, $\beta$-glucosidase, and phosphatase activities in treated substrate were $73.73 \%, 17.20 \%$, and $16.23 \%$ greater, respectively, than in the control substrate (Fig. 3). Urease activity is reportedly enhanced by chlorpyrifos, acetochlor, or both together [36]. Urease is more responsive than phosphatase to pesticides in soils [37]. $\beta$-glucosidase may regulate the supply carbon for

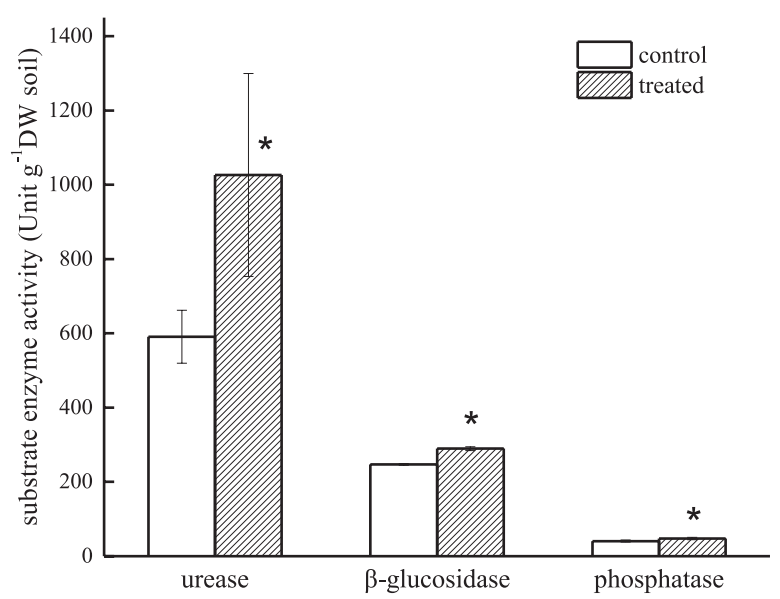

Fig. 3. Effect of chlorpyrifos on enzyme activities in substrate samples from constructed wetlands. Data are presented as means $\pm \mathrm{SE}(\mathrm{n}=9)$. Asterisks $(*)$ indicate significant differences from the control group $(\mathrm{P}<0.05)$. Enzyme activity units for urease, $\beta$-glucosidase, and phosphatase are $\mu \mathrm{g}$-nitrophenol $\mathrm{g}^{-1} \mathrm{DW}$ soil $\mathrm{h}^{-1} 37^{\circ} \mathrm{C}$, $\mu \mathrm{g}$ p-nitrophenol $\mathrm{g}^{-1} \mathrm{DW}$ soil $\mathrm{h}^{-1} 37^{\circ} \mathrm{C}$, and $\mu \mathrm{g}$ nitrogen $\mathrm{g}^{-1} \mathrm{DW}$ soil $48 \mathrm{~h}^{-1} 37^{\circ} \mathrm{C}$, respectively. 


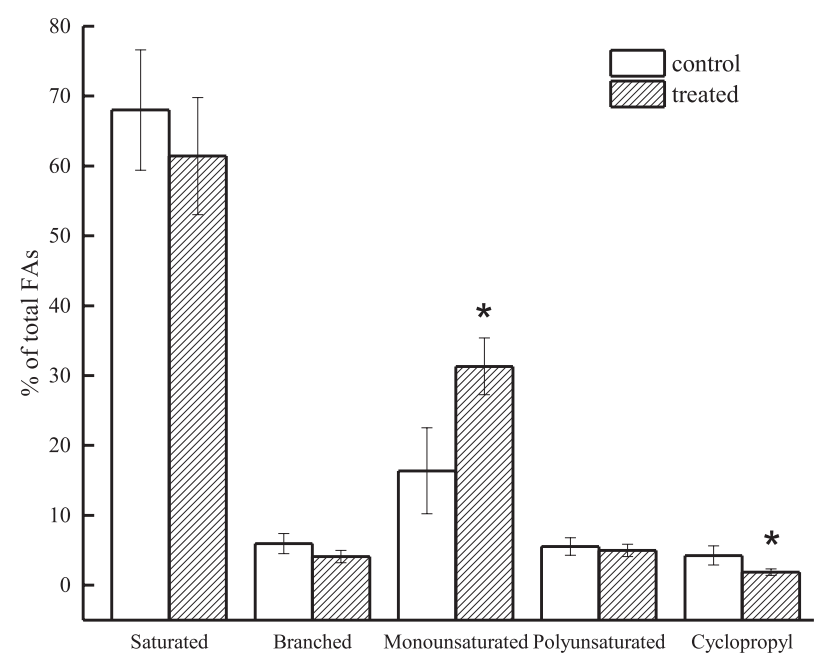

Fig. 4. Effect of chlorpyrifos on relative abundance of different FAME groups (\% of total FAs) in substrate samples collected from constructed wetlands.

microorganisms thatare unable to directlyutilize cellobiose [16]. Because of its role in the $\mathrm{C}$ cycle, $\beta$-glucosidase has microbial ecological significance and has been suggested as an assay for the 40 decomposition rate of organic matter [38]. $\beta$-glucosidase, acid phosphomonoesterase, alkaline phosphomonoesterase, and phosphotriesterase activities are reportedly stimulated by 10 pesticides [39]. Significant correlation has been observed between activity of the phosphatase, phosphotriesterase, and chlorpyrifos biotransformation rates [40]. The activities of all three soil enzymes in the present study increased with chlorpyrifos treatment, indicating stimulation of elements $\mathrm{N}, \mathrm{C}$, and $\mathrm{P}$ cycles.

\section{Microbial Community Structure by Analysis of EL-FAME}

Nineteen FAMEs from C9 to C20 were detected by GC-MS, including saturated, branched-chain, cyclopropyl, monounsaturated, and polyunsaturated FAs. Saturated FAs showed the highest relative abundance (Fig. 4), followed by monounsaturated FAs, polyunsaturated FAs, branched-chain FAs, and cyclopropyl FAs. Only monounsaturated FAs were obviously more abundant in treated substrates than in control substrates (16.37\% vs. $31.32 \%)$. In contrast, cyclopropyl FA was less abundant in treated substrates than in control substrates $(4.25 \%$ vs. $1.87 \%)$. The remaining FAs were not significantly different between groups.

As shown in Table 2, four ratios were used to describe the character of microbial community structure. No differences were found between control and treated groups in Fungal/bact or trans/cis. (i15:0+a15:0)/16:0 was significantly higher in control substrate than in treated substrate (0.162 and 0.082, respectively), whereas MUFA/ Branched was significantly lower in control substrate than in treated substrate (3.024 and 8.691, respectively). Diversity indices of Shannon-Wiener index and Simpson index were also explored. Microbial community diversity, as determined using the Sannon-Wiener and Simpson indices, was not affected by either simulation wastewater or chlorpyrifos.

FAMEs were divided into four groups according to the classification method described by Findlay [41]. We found significant differences between treatment and control substrates in the relative abundance of each group, with the exception of group I. In comparison to the relative abundance of FAMEs in control substrates,

Table 2. Ratios of characteristic fatty acids and diversity indices in substrate samples collected from constructed wetlands before and after a 30-d experimental period.

\begin{tabular}{|c|c|c|c|c|}
\hline & & Before & & \\
\hline & & & treated & control \\
\hline \multirow{4}{*}{ Ratios } & Fungal/bact & $0.33 \pm 0.02^{\mathrm{a}}$ & $0.21 \pm 0.01^{\mathrm{b}}$ & $0.23 \pm 0.02^{\mathrm{b}}$ \\
\hline & $(\mathrm{i} 15: 0+\mathrm{a} 15: 0) / 16: 0$ & $0.15 \pm 0.04^{\mathrm{b}}$ & $0.08 \pm 0.02^{\mathrm{c}}$ & $0.16 \pm 0.05^{\mathrm{a}}$ \\
\hline & trans/cis & $1.23 \pm 0.42^{\mathrm{b}}$ & $1.63 \pm 0.48^{\mathrm{a}}$ & $2.02 \pm 0.24^{\mathrm{a}}$ \\
\hline & MUFA/Branched & $2.24 \pm 0.28^{c}$ & $8.69 \pm 0.82^{\mathrm{a}}$ & $3.02 \pm 0.70^{\mathrm{b}}$ \\
\hline \multirow{2}{*}{ Diversity indices } & Shannon-Wiener & $2.00 \pm 0.21^{\mathrm{a}}$ & $1.95 \pm 0.11^{\mathrm{a}}$ & $2.02 \pm 0.25^{\mathrm{a}}$ \\
\hline & Simpson & $0.19 \pm 0.04^{\mathrm{a}}$ & $0.20 \pm 0.04^{\mathrm{a}}$ & $0.20 \pm 0.06^{\mathrm{a}}$ \\
\hline \multirow{4}{*}{$\begin{array}{c}\text { Group } \\
\text { (\% of total FAs) }\end{array}$} & Group I & $6.89 \pm 1.32^{\mathrm{a}}$ & $4.73 \pm 0.52^{b}$ & $5.84 \pm 1.13^{\mathrm{ab}}$ \\
\hline & Group II & $16.83 \pm 3.24^{c}$ & $34.25 \pm 8.03^{\mathrm{a}}$ & $18.47 \pm 7.53^{b}$ \\
\hline & Group III & $6.68 \pm 1.44^{\mathrm{a}}$ & $4.07 \pm 0.78^{\mathrm{b}}$ & $6.79 \pm 1.32^{\mathrm{a}}$ \\
\hline & Group IV & $4.69 \pm 1.36^{\mathrm{a}}$ & $2.25 \pm 0.54^{\mathrm{b}}$ & $4.53 \pm 0.95^{\mathrm{a}}$ \\
\hline
\end{tabular}

Group I: Polyunsaturated FA, indicators of eukaryotic microbes; Group II: monounsaturated FA, indicators of aerobic prokaryotic microbes; Group III: branched-chain FA(C14-C16), indicators of anaerobic and Gram-positive bacteria; Group IV: branched-chain FA(C17-C19), including methyl and cyclopropyl FA, indicators of sulfate-reducing bacteria and other anaerobic bacteria. 

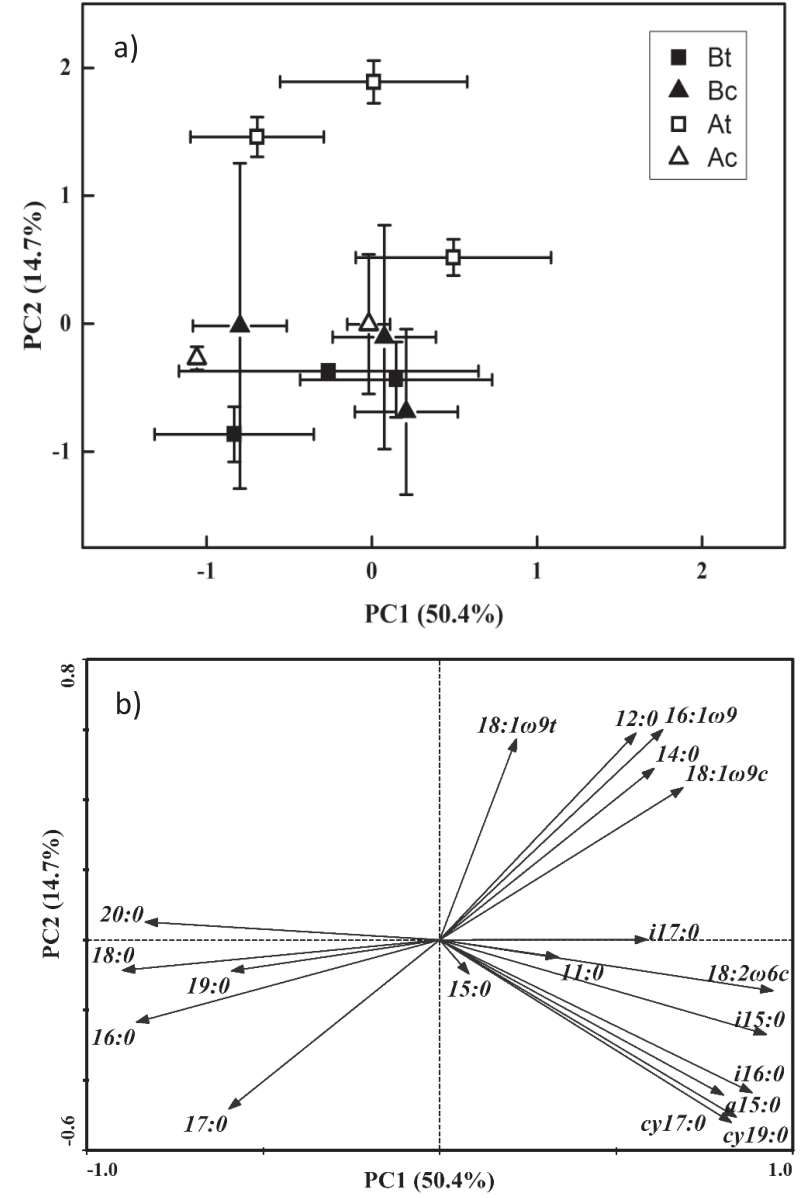

Fig. 5. Sample scores plot a) and loadings of individual fatty acids b) based on the PCA analysis of EL-FAMEs profiles. Bt, $\mathrm{Bc}, \mathrm{At}$, and Ac indicate substrate samples from treatment and control groups before and after chlorpyrifos treatment.

group II FAMEs were $85.43 \%$ more abundant in treated substrates, whereas group III FAMEs were 40.04\% less abundant and group IV FAMEs were 50.31\% less abundant.

Variations in microbial community structure were analyzed by PCA. As shown in Fig. 5, the first principle component (PC1) explained $50.4 \%$ of the total variance and PC2 explained $14.7 \%$ of the total variance. The microbial community structure in the control group was almost unchanged throughout the course of the experiment, but it was separated along PC2 from the community structure of the treated group (Fig. 5a).

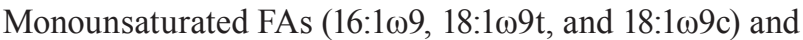
two saturated FAs (12:0 and 14:0) were most positively correlated with PC2, while cyclopropyl FAs (cy17:0 and cy19:0), two branched-chain FAs (a15:0 and i16:0), and saturated FA 17:0 were most negatively correlated with PC2 (Fig. 5b). These FAs could explain the changes in substrate microbial community structure in CWs after treatment with wastewater-borne chlorpyrifos.

The ratio of FAME fungal-to-bacterial biomarkers reflected changes in soil health, mainly soil organic matter and inorganic $\mathrm{N}$ concentrations [22]. The ratio of trans/ cis FAMEs indicates the degree of stress in the microbial community [42]. The (i15:0+a15:0)/16:0 ratio reflects the proportion of microbes that are bacteria [43], and the ratio of MUFA/Branched indicates the comparative advantage of aerobic to anaerobic bacteria. The observed changes in (i15:0+a15:0)/16:0 and MUFA/Branched indicate that the overall proportion of the microbial community that was made up of bacteria decreased after treatment with chlorpyrifos, but the proportion of aerobic bacteria increased. This suggests that aerobic bacteria may be responsible for chlorpyrifos degradation by using it as a carbon source. Three aerobic bacterial consortia developed from pesticide-contaminated soils are reported to be able to degrade chlorpyrifos efficiently [44]. A major chloropyrifos metabolite, 3,5,6-trichloro-2-pyridinol (TCP), has been identified in the degradation process by cyanobacterium Synechocystis sp. strain PUPCCC 64 [2]. Another strain of Alcaligenes sp., capable of degrading chlorpyrifos and its major metabolite TCP, has been isolated from paddy field soil [45]. Fungi are also capable of degrading chlorpyrifos, but there are fewer fungal species than bacterial species degrading this pesticide [46]. Fungal/bacterial ratios are indicators for both soil health and the sustainability of agro ecosystems [22, 47]. We found no negative influence of removing chlorpyrifos from wastewater by $\mathrm{CWs}$ on microbial communities in the CW substrate.

\section{Conclusions}

Chlorpyrifos at a concentration of $1 \mathrm{mg} \mathrm{L}^{-1}$ caused inhibition of growth and photosynthetic efficiency of I. Pseudoacorus in CWs. Although the antioxidant system was apparently induced by chlorpyrifos treatment, I. Pseudoacorus was able to cope with these changes and protect itself against oxidative damage. The activities of urease, $\beta$-glucosidase, and phosphatase in substrate samples were increased by chlorpyrifos treatment. However, the degree of stress in the microbial community and the health of the substrate were not greatly affected by chlorpyrifos. The biotic system in CWs is capable of resisting pesticide chlorpyrifos. Therefore, $\mathrm{CWs}$ may be an appropriate choice for disposal of wastewater containing chlorpyrifos or other organophosphorus pesticides that have a similar degradation pathway.

\section{Acknowledgements}

This study was supported by the Major Science and Technology Program for Water Pollution Control and Treatment of China's 12th Five-Year Plan (No. 2012ZX07101007-005) and the National Natural Science Foundation of China (Nos. 30870221, 51178452, and 50909091). We would like to thank Dr. Lu Z Y for his support on statistical software. 


\section{References}

1. CRAWFORD K.D., WEINSTEIN J.E., HEMINGWAY R.E., GARNER T.R., GLOBENSKY G. A Survey of Metal and Pesticide Levels in Stormwater Retention Pond Sediments in Coastal South Carolina. Arch. Environ. Con. Tox. 58 (1), 9, 2010.

2. SINGH D.P., KHATTAR J.I.S., NADDA J., SINGH Y., GARG A., KAUR N., GULATI A. Chlorpyrifos degradation by the cyanobacterium Synechocystis sp strain PUPCCC 64. Environ. Sci. Pollut. Res. 18 (8), 1351, 2011.

3. XU D.J., JIN M.Q., GU Z.Y., XU X.L., XU G.C. Review of the Application of Chlorpyrifos in the Control of Rice Pest Insects. Modern Agrochemicals (in Chinese). 6 (2), 6, 2007.

4. USEPA. Pesticide Industry Sales and Usage Report, Washington, DC; 2011.

5. JIANG Z.H. Analysis of marketing and development trend of chlorpyrifos. The New Century of Agrochem. 10, 45, 2010 [In Chinese].

6. PEDERSEN J.A., YEAGER M.A., SUFFET I.H. Organophosphorus insecticides in agricultural and residential runoff: Field observations and implications for total maximum daily load development. Environ. Sci. Technol. 40 (7), 2120, 2006.

7. ROGERS M.R., STRINGFELLOW W.T. Partitioning of chlorpyrifos to soil and plants in vegetated agricultural drainage ditches. Chemosphere. 75 (1), 109, 2009.

8. STEARMAN G.K., GEORGE D.B., CARLSON K., LANSFORD S. Pesticide removal from container nursery runoff in constructed wetland cells. J. Environ. Qual. 32 (4), 1548,2003

9. ELSAESSER D., BLANKENBERG A.G.B., GEIST A., MAEHLUM T., SCHULZ R. Assessing the influence of vegetation on reduction of pesticide concentration in experimental surface flow constructed wetlands: Application of the toxic units approach. Ecol. Eng. 37 (6), 955, 2011.

10. WANG P., YANG X., HUANG W.W., ZHANG M., LU W.H., ZHAO H.T., WANG J., LIU H. L., DONG A. J., ZHANG H., XU R.B., ZOU P., CHENG C.L., ZHANG Y.C., JING J. Effect of pesticide 1- 6-chloro-3-methyl-pyridyl-8-nitro-7methyl-1 2356 7-hexahydro imidazo $(1,2 \mathrm{a})$-pyridine when responding to a wheat plant's antioxidant defense system. Food Chem. 146, 569, 2014

11. FRANCO A.R., PEREIRA S.I.A., CASTRO P.M.L. Effect of benfluralin on Pinus pinea seedlings mycorrhized with Pisolithus tinctorius and Suillus bellinii - Study of plant antioxidant response. Chemosphere. 120, 422, 2015.

12. MITTLER R. Oxidative stress, antioxidants and stress tolerance. Trends Plant Sci. 7 (9), 405, 2002.

13. FRÖHLICH M., KUTSCHERA U. Changes in Soluble Sugars and Proteins during Development of Rye Coleoptiles. J. Plant. Physiol. 146 (1-2), 121, 1995.

14. GONZÁLEZ M.G., GALLARDO J.F., GÓMEZ E., MASCIANDARO G., CECCANTI B., PAJARES S. Potential universal applicability of soil bioindicators: evaluation in three temperate ecosystems. Ciencia del suelo. 25 (2), 151, 2007.

15. BALASUBRAMANIAN A., DURAIRAJPANDIAN V., ELUMALAI S., MATHIVANAN N., MUNIRAJAN A.K., PONNURAJ K. Structural and functional studies on urease from pigeon pea (Cajanus cajan). Int. J. Biol. Macromol. 58, 301, 2013.

16. TURNER B. L., HOPKINS D. W., HAYGARTH P. M., OSTLE N. $\beta$-Glucosidase activity in pasture soils. Appl. Soil. Ecol. 20 (2), 157, 2002.
17. SIUDA W., CHRÓST R. J. Decomposition and Utilization of Particulate Organic Matter by Bacteria in Lakes of Different Trophic Status. Pol. J. Environ. Stud. 11 (1), 53, 2002.

18. SCHNEIDER K., TURRION M.B., GRIERSON P.F., GALLARDO J.F. Phosphatase activity, microbial phosphorus, and fine root growth in forest soils in the Sierra de Gata, western central Spain. Biol. Fert. Soils. 34 (3), 151, 2001.

19. MERILES J.M., GIL S.V., CONFORTO C., FIGONI G., LOVERA E., MARCH G.J., GUZMAN C.A. Soil microbial communities under different soybean cropping systems: Characterization of microbial population dynamics, soil microbial activity, microbial biomass, and fatty acid profiles. Soil. Till. Res. 103 (2), 271, 2009.

20. KLOSE S., ACOSTA-MARTINEZ V., AJWA H.A. Microbial community composition and enzyme activities in a sandy loam soil after fumigation with methyl bromide or alternative biocides. Soil. Biol. Biochem. 38 (6), 1243, 2006.

21. MATTSSON M.K., LIU X.X., YU D., KONTRO M.H. Depth, soil type, water table, and site effects on microbial community composition in sediments of pesticidecontaminated aquifer. Environ. Sci. Pollut. Res. 22 (13), $10263,2015$.

22. MUMMEY D.L., STAHL P.D., BUYER J.S. Microbial biomarkers as an indicator of ecosystem recovery following surface mine reclamation. Appl. Soil. Ecol. 21 (3), 251, 2002.

23. XU J., GUO L.Q., DONG F.S., LIU X.G., WU X.H., SHENG Y., ZHANG Y., ZHENG Y.Q. Response of the soil microbial community to imazethapyr application in a soybean field. J. Environ. Sci. Heal. B. 48 (6), 505, 2013.

24. ANDERSON B.S., PHILLIPS B.A., HUNT J.W., WORCESTER K., ADAMS M., KAPELLAS N., TJEERDEMA R.S. Evidence of pesticide impacts in the Santa Maria River watershed, California, USA. Environ. Toxicol. Chem. 25 (4), 1160, 2006.

25. THOMATOU A.-A., ZACHARIAS I., HELA D., KONSTANTINOU I. Determination and risk assessment of pesticide residues in lake Amvrakia (W. Greece) after agricultural land use changes in the lake's drainage basin. Int. J. Environ. Anal. Chem. 93 (7), 780, 2013.

26. LIN C.C., KAO C.H. Abscisic acid induced changes in cell wall peroxidase activity and hydrogen peroxide level in roots of rice seedlings. Plant Sci. 160 (2), 323, 2001.

27. KONG X.S., YI X.F. Techniques of Plant Physiological Experiment Beijing: China Agriculture Press; 2008.

28. MICROBIOLOGY DEPARTMENT INSTITUTE OF SOIL SCIENCE CHINESE ACADEMY OF SCIENCES. Research Methods of Soil Microbes.: Science Press(China); 1985.

29. SCHUTTER M.E., DICK R.P. Comparison of fatty acid methyl ester (FAME) methods for characterizing microbial communities. Soil. Sci. Soc. Am. J. 64 (5), 1659, 2000.

30. DOGANLAR Z.B. Physiological and Genetic Responses to Pesticide Mixture Treatment of Veronica beccabunga. Water Air. Soil Poll. 223 (9), 6201, 2012.

31. RAMEL F., BIRTIC S., CUINE S., TRIANTAPHYLIDES C., RAVANAT J.L., HAVAUX M. Chemical Quenching of Singlet Oxygen by Carotenoids in Plants. Plant Physiol. 158 (3), 1267, 2012

32. TINOCO-OJANGUREN C., PEARCY R.W. A comparison of light quality and quantity effects on the growth and steady-state and dynamic photosyntetic characteristics of three tropical tree species. Funct. Ecol. 9, 22, 1995.

33. HE H.Z., LI Y.J., CHEN T.F., HUANG X.L., GUO Q., LI S.F., YU T.H., LI H.S. Butachlor induces some physiological 
and biochemical changes in a rice field biofertilizer cyanobacterium. Pest. Biochem. Physiol. 105 (3), 224, 2013.

34. HE H.Z., LI Y.J., CHEN T.F., HUANG X.L., GUO Q., LI S.F., YU T.H., LI H.S. Butachlor induces some physiological and biochemical changes in a rice field biofertilizer cyanobacterium. Pestic. Biochem. Phys. 105 (3), 224, 2013.

35. DOS SANTOS C.M., SILVA M.D. Physiological and biochemical responses of sugarcane to oxidative stress induced by water deficit and paraquat. Acta Physiol. Plant. 37 (8), 14, 2015.

36. MA A.J., HE R.H., JIANG X.Y., LIN Y.S. Effects of single and combined pollution of chlorpyrifos and acetochlor on soil enzyme activity and microbial biomass carbon. Journal of Ecology and Rural Environment (in Chinese). 24 (2), 57, 2008.

37. RAHMANSYAH M., ANTONIUS S., SULISTINAH N. Phosphatase and urease instability caused by pesticides present in soil improved by grounded rice straw. ARPN J. Agr. Biol. Sci. 4 (2), 56, 2009.

38. BRZEZINSKA M.S., KALWASINSKA A., LALKEPORCZYK E., BURKOWSKA-BUT A., JANKIEWICZ U. Rhizosphere Effect of Salix viminalis L. on Soil Enzyme Activity in a Wastewater Treatment Wetland. Clean-Soil Air Water. 44 (5), 563, 2016.

39. FLOCH C., CHEVREMONT A.-C., JOANICO K., CAPOWIEZ Y., CRIQUET S. Indicators of pesticide contamination: Soil enzyme compared to functional diversity of bacterial communities via Biolog ${ }^{\circledR}$ Ecoplates. Eur. J. Soil. Biol. 47 (4), 256, 2011.

40. KARPUZCU M.E., SEDLAK D.L., STRINGFELLOW W.T. Biotransformation of chlorpyrifos in riparian wetlands in agricultural watersheds: Implications for wetland management. J. Hazard. Mater. 244, 111, 2013.

41. FINDLAY R.H., KING G.M. Handbook of methods in aquatic microbial ecology. In: KEMP P.F., SHERR B.F., SHERR E.V., COLE J.J., editors. Quantitative description of microbial communities using lipid analysis., Lewis Publishers; 271, Boca Raton, 1993.

42. TROGL J., PAVLORKOVA J., PACKOVA P., SEJAK J., KURAN P., POPELKA J., PACINA J. Indication of Importance of Including Soil Microbial Characteristics into Biotope Valuation Method. Sustainability. 8 (3), 253, 2016.

43. RAJENDRAN N., MATSUDA O., IMAMURA N., URUSHIGAWA Y. Variation in Microbial Biomass and Community Structure in Sediments of Eutrophic Bays as Determined by Phospholipid Ester-Linked Fatty-Acids. Appl. Environ. Microb. 58 (2), 562, 1992.

44. LAKSHMI C.V., KUMAR M., KHANNA S. Biodegradation of Chlorpyrifos in Soil by Enriched Cultures. Curr. Microbiol. 58 (1), 35, 2009.

45. SILAMBARASAN S., ABRAHAM J. Kinetic studies on enhancement of degradation of chlorpyrifos and its hydrolyzing metabolite TCP by a newly isolated Alcaligenes sp JAS1. J Taiwan. Inst. Chem. E. 44 (3), 438, 2013.

46. WU C.Y., CHEN N., LI Q.F., HUANG X. Research Progress in Chlorpyrifos Degrading Microorganisms and Biodegrading Mechanisms. Chinese Journal of Tropical Crops. 32 (10), 1989, 2011 [In Chinese].

47. DE VRIES F.T., HOFFLAND E., VAN EEKEREN N., BRUSSAARD L., BLOEM J. Fungal/bacterial ratios in grasslands with contrasting nitrogen management. Soil. Biol. Biochem. 38 (8), 2092, 2006. 
